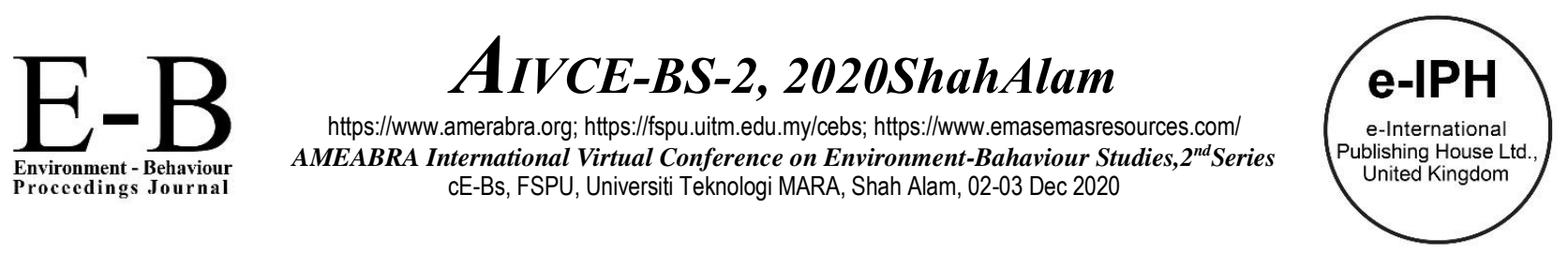

\title{
An overview of Wall Envelope Thermal Performance in Arid Climate Buildings
}

\author{
Yazeed Alsaqabi ${ }^{1}$, Abdulbasit Ali Almhafdy ${ }^{1}$, Ahmed AbdelMonteleb M. Ali1,2 \\ 1Department of Architecture, College of Architecture and Planning, \\ Qassim University, Qassim, 52571, Saudi Arabia. \\ 2Department of Architectural Engineering, Faculty of Engineering, \\ Assiut University, Assiut, 71515, Egypt
}

371117799@qu.edu.sa, a.almhafdy@qu.edu.sa, ahm.ali@qu.edu.sa, ahmed.abdelmonteleb@aun.edu.eg Tel: +96656008 6788

\begin{abstract}
Energy efficiency is an important issue that has been considered by many construction sectors. Recently, the research attention is focused on the thermal performance of the wall envelope, in particular, for its high energy consumption. This paper conducted a literature review highlighting the recent studies and research approach and methodology on the building wall envelope. Results indicate that climate, insulation and orientation are the key factors that should be considered on wall envelope design and installation.
\end{abstract}

Keywords: Wall Envelope, Orientation, Thermal Performance, Insulation Thickness

eISSN: 2398-4287@ 2020. The Authors. Published for AMER ABRA cE-Bs by e-International Publishing House, Ltd., UK. This is an open access article under the CC BYNC-ND license (http://creativecommons.org/licenses/by-nc-nd/4.0/). Peer-review under responsibility of AMER (Association of Malaysian Environment-Behaviour Researchers), ABRA (Association of Behavioural Researchers on Asians) and cE-Bs (Centre for Environment-Behaviour Studies), Faculty of Architecture, Planning \& Surveying, Universiti Teknologi MARA, Malaysia. DOI: https://doi.org/10.21834/ebpj.v5i15.2501

\subsection{Introduction}

The importance of wall envelope and energy saving has been highlighted by many scholars (Alaidroos \& Krarti, 2015). Buildings have an important role in reducing the negative impact on the environment (Alaidroos \& Krarti, 2015). The importance of design building envelopes are increasing in the last years (Ziapour et al., 2020).

In many countries, buildings consume $40 \%$ of the energy in global demand and use $60 \%$ of building energy for heating and cooling (Kaynakli, 2012). The consumption of heating and cooling energy can be reduced through the appropriate passive design and thermal performance of the building envelope, and thermal insulation of buildings is one of the most important tools in enhancing the thermal performance of walls and reducing energy consumption (Kaynakli, 2012).

The air conditioning of buildings consumes a large amount of energy load. For example, in American homes, heating and cooling loads consume $50 \%$ to $70 \%$ of energy, and usually more in severe desert climates (Al-Homoud, 2005). The amount of energy consumption also depends on the thermal performance of the building envelope (Al-Homoud, 2005).

Reducing pollution and raising energy efficiency has a fundamental role in achieving sustainable development and eradicating poverty (the 2030 Agenda for Sustainable Development). The shares of total energy consumption for heating, cooling and ventilation in commercial buildings in the United States of America, the United Kingdom and Spain are $48 \%, 55 \%$ and $52 \%$, respectively. Moreover, in residential buildings, energy consumption was $53 \%, 63 \%$ and $42 \%$, respectively (Pourghorban et al., 2020). Achieving sustainability need to increase efficiency on buildings (Pourghorban et al., 2020)

eISSN: 2398-4287C 2020. The Authors. Published for AMER ABRA cE-Bs by e-International Publishing House, Ltd., UK. This is an open access article under the CC BYNC-ND license (http://creativecommons.org/licenses/by-nc-nd/4.0/). Peer-review under responsibility of AMER (Association of Malaysian Environment-Behaviour Researchers), ABRA (Association of Behavioural Researchers on Asians) and cE-Bs (Centre for Environment-Behaviour Studies), Faculty of Architecture, Planning \& Surveying, Universiti Teknologi MARA, Malaysia.

DOI: https://doi.org/10.21834/ebpj.v5i15.2501. 


\subsection{Methodology}

This paper explored recent studies in the field of walls based on two main determinants. First, studies addressed the thermal performance of walls, second, studies that addressed the effect of the wall orientation on energy consumption.

Web of Science is the database that was used to conduct the research. The research conditions were whether the title contains one of the following words related to this study including, wall system, external wall, insulation, or walls. Besides, other research keywords included in the abstract: energy, heat, insulation, desert climate, or the Kingdom of Saudi Arabia.

Based on the keywords inquires, the papers selected will be explained, analyzed and reported in the finding section. Moreover, few papers were added to the references of this study using the snowballing technique.

\subsection{Objectives:}

This paper explored the related studies in wall envelopes and their impact on thermal performance inside the buildings. The aim is to highlight the possible future directions of research in the field of wall envelopes with special attention to the arid climates (Table 1).

Table 1. The key related studies on wall envelope that covered in this paper

\begin{tabular}{|c|c|c|c|c|}
\hline No. & Ref & Method & Parameters & Outcome \\
\hline 1 & $\begin{array}{l}\text { (Ziapour et al., } \\
\text { 2020) }\end{array}$ & $\begin{array}{l}\text { life cycle cost } \\
\text { and energy } \\
\text { savings }\end{array}$ & $\begin{array}{l}\text { composite } \\
\text { prefabricated } \\
\text { wall block, insulation } \\
\text { thickness }\end{array}$ & The optimum thickness of wall insulation depends on the weather conditions \\
\hline 2 & $\begin{array}{l}\text { (Pourghorban et al., } \\
\text { 2020) }\end{array}$ & simulation & $\begin{array}{l}\text { Reflective insulation } \\
\text { system }\end{array}$ & $\begin{array}{l}\text { A } 20 \mathrm{~mm} \text { air gap adjacent to reflective surfaces is the most appropriate system in the } \\
\text { wall application. }\end{array}$ \\
\hline 3 & (Sobhy et al., 2017) & $\begin{array}{l}\text { Experimental, } \\
\text { Simulation }\end{array}$ & Thermal insulation, & using cavity wall reducing $5 \%$ and $13 \%$ of cooling and heating loads, respectively. \\
\hline 4 & $\begin{array}{l}\text { (Al-Sanea et al., } \\
2016)\end{array}$ & $\begin{array}{l}\text { Thermal and } \\
\text { economic } \\
\text { analyses }\end{array}$ & $\begin{array}{l}\text { optimum R-values for } \\
\text { building walls }\end{array}$ & $\begin{array}{l}\text { configuration of the wall has the least affected on thermal performance, however, } \\
\text { affected by climate and insulation type. }\end{array}$ \\
\hline 5 & $\begin{array}{l}\text { (Mohamed Ali } \\
\text { Abdelrahman \& } \\
\text { Ahmad, 1991) }\end{array}$ & & $\begin{array}{l}\text { insulation thicknesses, } \\
\text { insulation materials }\end{array}$ & The most efficient to make the insulation on the outer layer of the wall. \\
\hline 6 & $\begin{array}{l}\text { (Derradji et al., } \\
2017)\end{array}$ & Experimental & insulation thickness & $\begin{array}{l}\text { expanded polystyrene has an optimum thickness in Algeria varies from } 1 \mathrm{~cm} \text { and } \\
2.5 \mathrm{~cm}\end{array}$ \\
\hline 7 & $\begin{array}{l}\text { (Daouas et al., } \\
2010)\end{array}$ & $\begin{array}{l}\text { Thermal and } \\
\text { economic } \\
\text { analyses }\end{array}$ & $\begin{array}{l}\text { insulation thicknesses } \\
\text { and materials }\end{array}$ & $\begin{array}{l}\text { Stone or brick sandwich wall and expanded polystyrene for insulation, with an optimal } \\
\text { thickness of } 5.7 \mathrm{~cm} \text {, can save energy up to } 58 \% \text {. }\end{array}$ \\
\hline 8 & $\begin{array}{l}\text { (Al-Sanea \& Zedan, } \\
\text { 2011) }\end{array}$ & $\begin{array}{l}\text { studied } \\
\text { numerically }\end{array}$ & thickness and location & $\begin{array}{l}\text { A Wall with three layers ( } 26 \mathrm{~mm} \text { for each) of insolation is the best performance, } \\
\text { followed by a wall with two layers ( } 39 \mathrm{~mm} \text { for each). }\end{array}$ \\
\hline 9 & $\begin{array}{l}\text { (M A Abdelrahman } \\
\text { et al., 1993) }\end{array}$ & Simulation & $\begin{array}{l}\text { Masonry } \\
\text { Materials }\end{array}$ & $\begin{array}{l}\text { Clay bricks cost } 13 \% \text { less than one built of concrete blocks, } 34 \% \text { less than one built } \\
\text { of sand-lime bricks and } 57 \% \text { less than one built of prefabricated concrete walls. }\end{array}$ \\
\hline 10 & $\begin{array}{l}\text { (Al-Hadhrami \& } \\
\text { Ahmad, 2009) }\end{array}$ & Numerical & $\begin{array}{l}\text { Masonry } \\
\text { Materials }\end{array}$ & $\begin{array}{l}\text { Red clay brick was found more thermally effective than concrete brick. } \\
\text { The use of insulating mortar in building walls increases the thermal resistance. }\end{array}$ \\
\hline 11 & $\begin{array}{l}\text { (Al-Sanea et al., } \\
2013 \text { ) }\end{array}$ & Numerical & $\begin{array}{l}\text { Masonry } \\
\text { Materials }\end{array}$ & $\begin{array}{l}\text { Thermal mass wall, concrete blocks and low absorption surfaces wall all have a } \\
\text { higher potential for saving energy. }\end{array}$ \\
\hline 12 & $\begin{array}{l}\text { (Alaidroos \& Krarti, } \\
\text { 2015) }\end{array}$ & simulation & $\begin{array}{l}\text { wall insulation, roof } \\
\text { insulation, window } \\
\text { area, window glazing, } \\
\text { window shading, and } \\
\text { thermal mass }\end{array}$ & $\begin{array}{l}\text { The analysis results showed that the KSA government could save up to } 36 \% \text { on } \\
\text { subsidies during the lifetime of each residential building without affecting }\end{array}$ \\
\hline
\end{tabular}

\subsection{Results and Discussions:}

Based on the reviewed papers in Table 1, heating and cooling loads can be reduced in several ways in severe desert conditions. The main finding that energy reduction roles are the appropriate design and careful selection of the building envelope materials and components. Besides, the wall structure, insulation properties, and climate are the key elements that affect the thermal performance inside the buildings in accordance with (Al-Sanea et al., 2016). Despite that the application of wall insulation is essential in hot regions based on (Ziapour et al., 2020), there is a clear gap in choosing the most appropriate insulation and economical as it is approved by (AlHomoud, 2005).

On the other hand, a study by (Pourghorban et al., 2020) stated that wall insulation is one of the most effective solutions in reducing heat loss from the building envelope and saving energy. However, there is a clear lack of information regarding wall R-value specification in Saudi Arabia (Al-Sanea et al., 2016). Besides the mentioned factors, another study by (Ahmad et al., 2014) concluded that the thermal performance of a wall envelope depends on the wall orientation and climate conditions.

Through the discussions and outcomes in Table 1, it is noted that the essential factors in determining the optimum wall thermal performance are as follows; (1) climate, (2) wall specification, and (3) orientation. Below, each point will be discussed separately. 
4.1 Climate:

The climate is one of the main factors determining the optimum type of wall envelope used in the building, as each climate has its conditions and requirements. In an arid climate, the required thermal insulation increases and conversely with the temperate regions(Alaidroos \& Krarti, 2015; Pourghorban et al., 2020; Ziapour et al., 2020). For instance, (Ziapour et al., 2020) have mentioned that there is a need to increase the wall thickness where the temperature is increased, which will improve energy performance. Furthermore, Al-Sanea investigated the best wall R-value for walls according to different climates in Saudi Arabia. The authors selected three different climate cities, Riyadh and Abha. The study concluded that in Riyadh, the cooling needs are more than heating during the year. While in Abah is the otherwise. The R-Value need for Riyadh is within the range between 2.84 and 2.05, while in Abha, the RValue need for Riyadh is within the range between 1.92 and 1.46.

\subsection{Wall Specifications}

According to the reviews on external walls in Table 1, there are many types of walls with different compositions, technology, and thermal performance (as seen in Table 2). Certain wall materials respond passively to thermal, while others need more insulation to enhance the thermal performance and, thus, need different strategies for optimum results. For instance, (Ahmadi et al., 2020) investigate the effect of using wheat straw as insulation in hollow bricks for minimizing the thermal loss in buildings.

Table 2. different types of walls based on the insulations.

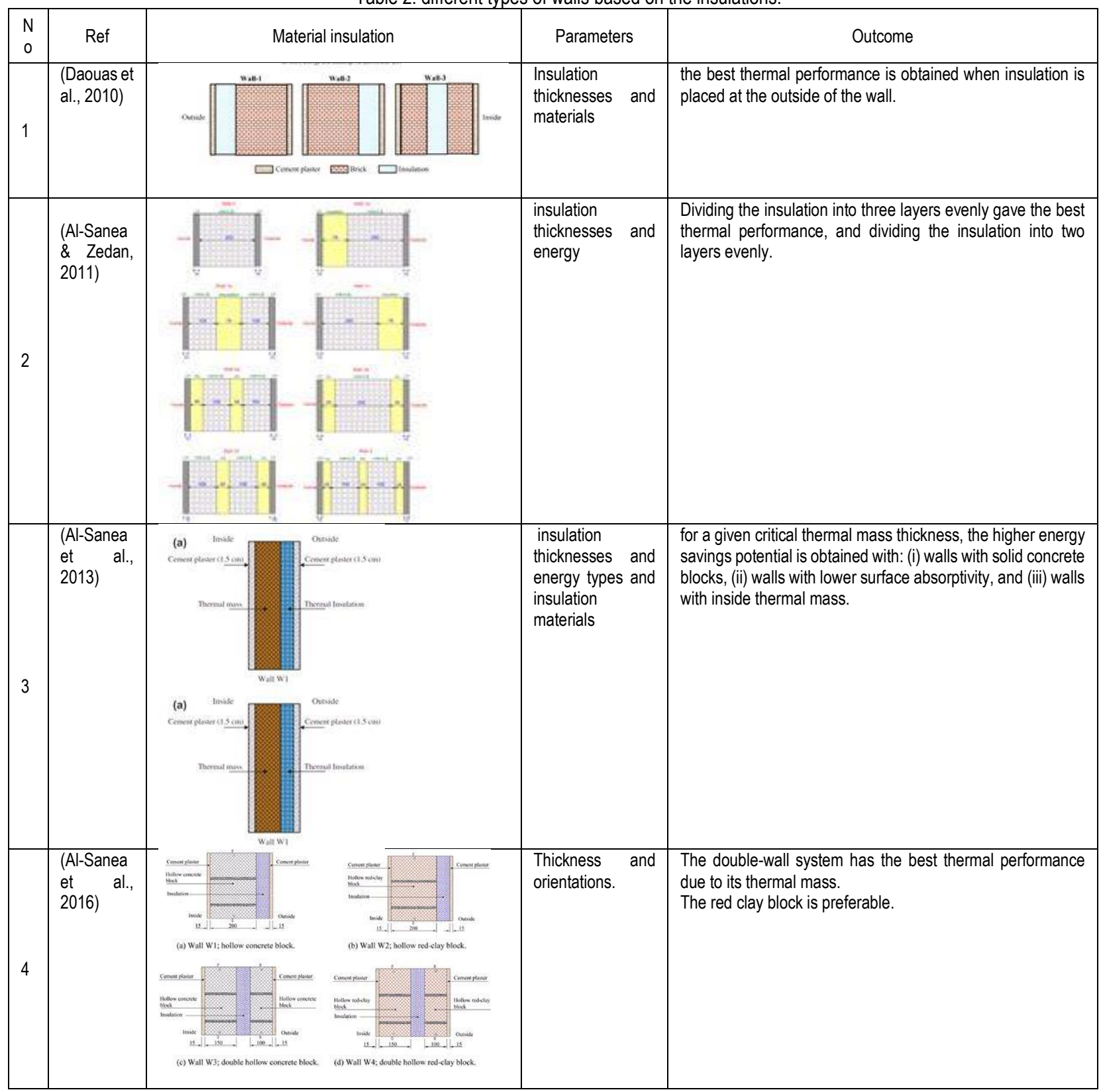




\begin{tabular}{|c|c|c|c|c|c|}
\hline 5 & $\begin{array}{l}\text { (Pourghor } \\
\text { ban et al., } \\
2020)\end{array}$ & 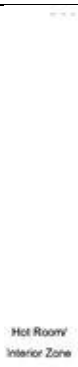 & 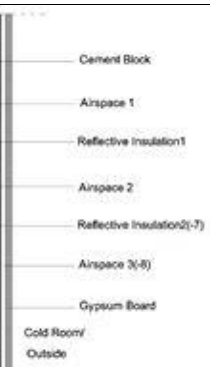 & $\begin{array}{l}\text { Insulation } \\
\text { thicknesses }\end{array}$ & $\begin{array}{l}\text { systems with a } 20 \mathrm{~mm} \text { air gap adjacent to reflective surfaces } \\
\text { are the most appropriate wall application systems. }\end{array}$ \\
\hline 6 & $\begin{array}{l}\text { (Sobhy et } \\
\text { al., 2017) }\end{array}$ & 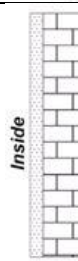 & $=5 \mathrm{~cm} \frac{1}{\frac{1}{1}}$ & $\begin{array}{l}\text { insulation } \\
\text { material and } \\
\text { insulation } \\
\text { thickness and } \\
\text { economic } \\
\text { analysis }\end{array}$ & $\begin{array}{l}\text { results indicate that the cavity wall contributes to an overall } \\
\text { reduction of } 13 \% \text { and } 5 \% \text { of the house heating and cooling } \\
\text { loads. }\end{array}$ \\
\hline
\end{tabular}

The insulators are classified into four groups corresponding to their functions, (1) Reflective, (2) Mass, (3) vacuum and (4) Nanosystems. In addition to insulation systems such as glass wool, rock wool, simplified polystyrene, and expanded polystyrene, they are classified into the mass system that considers weakness in the wall envelope (Pourghorban et al., 2020). On Reflective system, a study by (Pourghorban et al., 2020) concluded that hollow walls and reflective insulation systems in hot environments are ideal for 20 $\mathrm{cm}$ thickness. Also, in Saudi Arabia, the paper has compared nine types of clay bricks and two types of concrete bricks. The study concluded that red insulated bricks are the best choices, and the researcher emphasized that using an insulating material raises the thermal performance is better than mixing insulating materials in a brick mixture. It is also confirmed that using insulated mortar and filling cavities will increase the thermal wall performance (Al-Hadhrami \& Ahmad, 2009).

Optimum R-Value of the wall has been studied by (Al-Sanea et al., 2016). The study investigated the optimal thickness of thermal insulation for several cities in the KSA. The materials considered in the research for walls were determined, which are clay bricks and concrete bricks in the composition for one and two walls. Considering the thermal insulation polystyrene, polyurethane and rock wool, the results indicate that determining the optimal thickness of the insulation is influenced more by insulation, type, and climate rather than the wall layers and composition. The study also concluded that the most efficient wall is the rounded wall made of clay bricks using polystyrene.

Another study by (Sobhy et al., 2017) in Morocco stated that a $5 \mathrm{~cm}$ hollow inside the wall is the best among six other walls and achieved energy savings of about $13 \%$ for heating and $5 \%$ for cooling.

On the other hand, for distribution of thermal insulation in the structure of the wall, the research by (Al-Sanea \& Zedan, 2011) indicated that dividing the optimal thickness of the insulation into three layers gives the highest thermal performance, followed by dividing the insulation in the wall into two layers, followed by the insulation being one layer.

\subsection{Orientation:}

The wall orientation is one of the most critical variables affecting the external wall thermal performance, as each one faces its thermal conditions. According to the external walls of a building in Tunis, (Daouas, 2011) mentioned that the eastern and western walls are the worst in thermal performance in the summer season, and the northern walls are the worst in thermal performance in winter.

Another research by (Pekdogan \& Basaran, 2017), done in Izmir, concluded that the northern wall has less heat gain than other directions during the summer period. While in winter, it has the highest heat loss. In a study of the effect of orientation on a green wall, the researcher concluded that the effect of the wall on the eastern direction is reduced by 15 degrees Celsius, while the southern façade has lowered the temperature by 16 degrees Celsius, while the western façade has decreased by 16.4 degrees Celsius.

Table 3: The studies considered the wall orientation parameters

\begin{tabular}{|c|l|c|c|l|}
\hline No & \multicolumn{1}{|c|}{ Ref } & Wall Orientation & $\begin{array}{c}\text { Place and } \\
\text { climate }\end{array}$ & Outcome \\
\hline 1 & (Daouas, 2011) & N/S/E/W & Tunisia / Arid & $\begin{array}{l}\text { the west and east-facing walls are the least favorites in the cooling } \\
\text { season, whereas the north-facing wall is the least favorite in the } \\
\text { heating season }\end{array}$ \\
\hline 2 & $\begin{array}{l}\text { (Pekdogan \& Basaran, } \\
2017)\end{array}$ & $\mathrm{N} / \mathrm{S} / \mathrm{E} / \mathrm{W}$ & $\begin{array}{c}\text { Izmir / hot } \\
\text { summer and } \\
\text { cold winter }\end{array}$ & $\begin{array}{l}\text { The researcher concluded that the northern wall is less heat gain } \\
\text { than other directions during the summer period. While in winter, it } \\
\text { is the highest in heat loss. }\end{array}$ \\
\hline
\end{tabular}




\begin{tabular}{|c|l|c|c|l|}
\hline 3 & (Pérez et al., 2017) & S / E / W & $\begin{array}{l}\text { In a study of the effect of orientation on a green wall, the researcher } \\
\text { concluded that the effect of the wall on the eastern direction is } \\
\text { reduced by 15 degrees Celsius, while the southern façade has } \\
\text { lowered the temperature by 16 degrees Celsius, while the western } \\
\text { façade has decreased by 16.4 degrees Celsius. }\end{array}$ \\
\hline
\end{tabular}

\subsection{Conclusion}

According to previous discussions of literature and the results of practical and laboratory studies, it is noted that the successive and continuous contributions to the attempt to raise energy efficiency through the development of the thermal performance of walls. Three aspects that should be considered in the wall envelope research as follows:

\subsection{The climate aspect:}

Climate is one of the main determinants for optimum wall use in its thermal insulation for all buildings. It has been repeatedly emphasized in several studies. It is essential to analyze each city's weather data individually to determine the best practice for wall insulation and orientation.

\subsection{The wall aspect:}

There are many types of walls and systems. The optimum wall is determined based on the thermal performance required. The thermal performance of the wall increases by increasing the thermal resistance of its constituent materials. It is noted that the successful wall envelope can be achieved by adding insulating materials or using other insulation strategies such as air cavities or making a repetitive composition for walls.

\subsection{Orientation:}

According to the literature reviews, each direction should be investigated separately according to the climate condition and the building functions. Each façade can be differing in thickness and insulation properties. In some climates, like hot arid, the effect of orientation can be neglected if all the facades have the same wall properties.

\section{Acknowledgments}

Special thanks to the architecture department and the deanship of scientific research in Qassim University as they help in contacting technical lessons in the research techniques and guidelines courses. It was beneficial to make this paper done.

\section{Paper Contribution to Related Field of Study}

This is an overview of the current research approach in the field of wall envelope and its effect on the building's thermal performance. The expected contribution of this work is the future possible research directions which can be summarized as follows:

- New technologies should be addressed in future research, such as vacuum insulation and nanotechnologies.

- Real weather data should be considered in the research in a real and existing case study.

- Calibration between real weather data and simulation software results should be integrated for validation purposes.

\section{References}

Abdelrahman, M A, Said, S. A. M., \& Ahmad, A. (1993). A comparison of energy consumption and cost-effectiveness of four masonry materials in Saudi Arabia. Energy, 18(11), 1181-1186. https://doi.org/10.1016/0360-5442(93)90090-Z

Abdelrahman, Mohamed Ali, \& Ahmad, A. (1991). Cost-effective use of thermal insulation in hot climates. Building and Environment, 26(2), 189-194. https://doi.org/htps://doi.org/10.1016/0360-1323(91)90026-8

Ahmad, A., Maslehuddin, M., \& Al-Hadhrami, L. M. (2014). In situ measurement of thermal transmittance and thermal resistance of hollow reinforced precast concrete walls. Energy and Buildings, 84, 132-141. https://doi.org/https://doi.org/10.1016/j.enbuild.2014.07.048

Ahmadi, R., Souri, B., \& Ebrahimi, M. (2020). Evaluation of wheat straw to insulate fired clay hollow bricks as a construction material. Journal of Cleaner Production, 254, 120043. https://doi.org/https://doi.org/10.1016/j.jlepro.2020.120043

Al-Hadhrami, L. M., \& Ahmad, A. (2009). Assessment of thermal performance of different types of masonry bricks used in Saudi Arabia. Applied Thermal Engineering, 29(5-6), 1123-1130. https://doi.org/10.1016/j.applthermaleng.2008.06.003

Al-Homoud, D. M. S. (2005). Performance characteristics and practical applications of common building thermal insulation materials. Building and Environment, 40(3), 353-366. https://doi.org/https://doi.org/10.1016/j.buildenv.2004.05.013

Al-Sanea, S. A., \& Zedan, M. F. (2011). Improving thermal performance of building walls by optimizing insulation layer distribution and thickness for same thermal mass. Applied Energy, 88(9), 3113-3124. https://doi.org/https://doi.org/10.1016/j.apenergy.2011.02.036 
Al-Sanea, S. A., Zedan, M. F., \& Al-Hussain, S. N. (2013). Effect of masonry material and surface absorptivity on critical thermal mass in insulated building walls. Applied Energy, 102, 1063-1070. https://doi.org/https://doi.org/10.1016/j.apenergy.2012.06.016

Al-Sanea, S. A., Zedan, M. F., Al-Mujahid, A. M., \& Al-Suhaibani, Z. A. (2016). Optimum R-values of building walls under different climatic conditions in the Kingdom of Saudi Arabia. Applied Thermal Engineering, 96, 92-106. https://doi.org/10.1016/j.applthermaleng.2015.11.072

Alaidroos, A., \& Krarti, M. (2015). Optimal design of residential building envelope systems in the Kingdom of Saudi Arabia. Energy and Buildings, 86, $104-117$. https://doi.org/10.1016/i.enbuild.2014.09.083

Daouas, N. (2011). A study on optimum insulation thickness in walls and energy savings in Tunisian buildings based on analytical calculation of cooling and heating transmission loads. Applied Energy, 88(1), 156-164. https://doi.org/https://doi.org/10.1016/j.apenergy.2010.07.030

Daouas, N., Hassen, Z., \& Aissia, H. Ben. (2010). Analytical periodic solution for the study of thermal performance and optimum insulation thickness of building walls in Tunisia. Applied Thermal Engineering, 30(4), 319-326. https://doi.org/https://doi.org/10.1016/j.applthermaleng.2009.09.009

Derradji, L., Imessad, K., Amara, M., \& Boudali Errebai, F. (2017). A study on residential energy requirement and the effect of the glazing on the optimum insulation thickness. Applied Thermal Engineering, 112, 975-985. https://doi.org/https://doi.org/10.1016/j.applthermaleng.2016.10.116

Kaynakli, O. (2012). A review of the economical and optimum thermal insulation thickness for building applications. Renewable and Sustainable Energy Reviews, 16(1), 415-425. https://doi.org/https://doi.org/10.1016/j.rser.2011.08.006

Pekdogan, T., \& Basaran, T. (2017). Thermal performance of different exterior wall structures based on wall orientation. Applied Thermal Engineering, 112, 15-24. https://doi.org/10.1016/j.applthermaleng.2016.10.068

Pérez, G., Coma, J., Sol, S., \& Cabeza, L. F. (2017). Green facade for energy savings in buildings: The influence of leaf area index and facade orientation on the shadow effect. Applied Energy, 187, 424-437. https://doi.org/10.1016/j.apenergy.2016.11.055

Pourghorban, A., Kari, B. M., \& Solgi, E. (2020). Assessment of reflective insulation systems in wall application in hot-arid climates. Sustainable Cities and Society, 52, 101734. https://doi.org/https://doi.org/10.1016/j.scs.2019.101734

Sobhy, l., Brakez, A., \& Benhamou, B. (2017). ANALYSIS FOR THERMAL BEHAVIOR AND ENERGY SAVINGS OF A SEMI-DETACHED HOUSE WITH DIFFERENT INSULATION STRATEGIES IN A HOT SEMI-ARID CLIMATE. Journal of Green Building, 12(1), 78-106. https://doi.org/10.3992/1552-6100.12.1.78

Ziapour, B. M., Rahimi, M., \& Yousefi Gendeshmin, M. (2020). Thermoeconomic analysis for determining optimal insulation thickness for new composite prefabricated wall block as an external wall member in buildings. Journal of Building Engineering, 31, 101354. https://doi.org/https://doi.org/10.1016/j.jobe.2020.101354 